\title{
Assessing Instructional Resources and Students' Self-Employment Readiness through Marketing Trade Subject in Lagos State, Nigeria
}

\author{
Olusegun Ezekiel Alao*, Ngozi Faith Onah \\ Department of Arts and Social Sciences Education, Faculty of Education University of Lagos, \\ Akoka, Lagos, Nigeria \\ *Corresponding author, e-mail: ealao@unilag.edu.ng
}

\begin{abstract}
The challenges of youth unemployment and the need for a viable vocational and entrepreneurship education necessitated the introduction of trade/entrepreneurship subjects at senior secondary schools in Nigeria. Therefore, this study aimed at assessing the availability and functionality of the recommended instructional resources and the self-employment readiness of students of Marketing Trade subject. The study answered three research questions and tested one research hypothesis. The descriptive survey research design was adopted for the study. The population for the study comprised 1367 students and teachers of Marketing Trade subject in the selected public senior secondary schools in Education District IV of Lagos State, Nigeria. The sample of the study comprised 308 students and 9 available teachers of Marketing Trade subject randomly and purposively selected respectively from the population. The research instrument used was structured questionnaire. The Cronbach Alpha correlation coefficient used to determine the internal consistency of the research instrument yielded an average index of 0.88 . The research questions and hypothesis data were analysed using bar-charts, mean, standard deviation and Pearson Product Moment of Correction statistical tools as appropriate. The findings show the recommended instructional resources were not adequately available and functioning in schools, and as a result, students lacked the self-efficacy and competences for self-employment readiness as marketers and entrepreneurs. It was therefore recommended that Government and other stakeholders should collaborate to provide necessary and adequate funding and instructional resources for the effective implementation of Marketing Trade subject in Nigeria.
\end{abstract}

Keywords: Marketing, Trade Subject, Self-Employment Readiness, Instructional Resources, Secondary Schools Students.

How to Cite: Alao, O. E. \& Onah, N. F. (2020). Assessing Instructional Resources and Students' SelfEmployment Readiness through Marketing Trade Subject in Lagos State, Nigeria. Journal of Vocational Education Studies, 3(1), 1-12. DOI: https://doi.org/10.12928/ joves.v3i2.2744.

\section{INTRODUCTION}

The rate of youth unemployment is increasing daily, especially in the developing countries. Attempts at solving this problem of unemployment among the youth led to the introduction of entrepreneurship/trade subjects at secondary schools in Nigeria (Yusuf, 2018). In order to achieve the aims and objectives of Marketing Trade subject at secondary schools, both human and non-human instructional resource need to be adequately available. Marketing Trade subject is entrepreneurial and vocational in nature and practice; specific and requisite competences are expected to be acquired by students for both employability and self-employment through the subject. Availability of relevant, modern instructional resources is a sine qua non for any skill-acquisition or vocational subject. Therefore, the Nigerian Educational Research and Development Council (2007) recommended several instructional resources for the effective teaching and learning of Marketing Trade subject to ascertain learners' acquisition and demonstration of both employability and selfemployment competences at graduation. It is considered necessary to assess the availability 
of the recommended instructional resources in the actual implementation of Marketing Trade subject at senior secondary schools in Nigeria.

NERDC (2007) highlights the objectives of Marketing Trade subject as follows:

i. To acquire the knowledge, skills and technical concepts needed to prepare marketing as a profession.

ii. To inculcate the attitudinal changes and behaviour that are production-orientation such as conscientious of the world of work and dignity of the world of work and dignity of labour.

iii. To enable students take advantage of the various government economic policies on poverty eradication, wealth creation, employment generation and to Microfinance institutions.

iv. To ensure maximally satisfactory self-employment.

Marketing, like other trade subjects, is a skill-based as well as entrepreneurialoriented subject aiming at preparing the secondary school students for self-employment, poverty eradication, wealth creation, and sustainable development of our economy. Olokundun, Falola, Stephen and Inelo (2014) stressed the need for teaching before students can acquire and practice entrepreneurship. Therefore, marketing cannot be taught mainly theoretically. Mbanefo and Eboka (2017) opined that the focus of instructional strategies in any entrepreneurial discipline or subject should be on the acquisition of relevant innovative competences, which majorly depend on the availability and functionality of relevant instructional resources. It is a necessity for the school management to have the instructional resources ready for the teaching and learning of trade subjects in the schools even though teachers would need to improvise. Instructional resources promote effective learning and bring about concrete exposure to learners. Any educational curriculum void of instructional resources is illogical and improbable (McGrant, 2002). This realization therefore demands for necessary equipment, facilities and tools students must manipulate for the acquisition of employability and self-employment skills and competences (Orji, 2013). Instructional resources, according to McGrant (2002), could take diverse forms such as visual, auditory, kinesthetic, print, computer-aided materials, internet facilities, infrastructure, and live performance or display. Cotta (2018) explains that common instructional resources could be in form of paper material, electronic/electrical gadgets, physical facilities, and tools, among others, used for knowledge and skills acquisition. NERDC (2007) mentioned Marketing laboratory, departmental goods shop, computers, laptops, projectors, T.V. set, Marketing plans documents, Electronic marketing Packages, and Newspapers among the instructional resources that must be available if Marketing Trade subject would achieve its aims and objectives in senior secondary schools in Nigeria. Relevant instructional resources need to be acquired by the school management and government for easy transfer of knowledge and skills from the professionals to the learners in Marketing trade subject. Ukala (2018) maintains that management principles should be applied to the availability and utilization of instructional resources used for trade subjects in senior secondary schools. There is need for periodic assessment of instructional resources in schools to ensure unbroken progress in the process of acquiring entrepreneurship skills, which are indispensable to achieving sustainable development in the nation.

In determining the employability competences that secondary school students must acquire, considerable thought should be given to the twenty-first competences necessary for the attainment of the sustainable development goals (SGDs, 2030). Nicholas and Shubha (2013) also recognized the need to improve the employability skills of secondary school

Volume 3, Number 2, November 2020 
students, especially in sub-Saharan African countries. Sayuti and Mujiarto (2018) identified communication skills, problem-solving skills, innovative skills, creativity skills, cognitivebased skills, lifelong learning skills, and technology skills as employability competences that must be promoted by any high school vocational/entrepreneurship curriculum. In addition to the vocational and technical skills, secondary school students need transferable skills for them to be well equipped with the twenty-first century globalized economy competences to eradicate poverty and attain sustainable development. Some of these transferable competences needed include communication skills, problem-solving skills, punctuality, and flexibility. Valerio, Parton and Robb (2014) also identified financial literacy skills, leadership, creativity, entrepreneurial mindset, self-confidence, risk propensity, selfefficacy, motivation and resilience as essential competences that can engender selfemployment readiness of students in secondary schools. Lackeus (2015) buttressed on the need to expose students to practical problem-solving entrepreneurship engagement through continuous interactions with learning resources within the school and employers of labour in the communities. Interaction of students of Marketing Trade subject with relevant and adequate instructional resources will engender increased marketing skills and competences.

Fasasi (2014) defines resources in teaching and learning as all categories of materials that can facilitate effective pedagogies and learning for the teachers and students respectively. McGrant (2002) defined instructional resources as those things used by instructors and learners within and outside the classroom setting to ease learning. Instructional resources are indispensable to the achievement of the goals and objectives of teaching and learning at any educational level. Self-employment readiness is the ability of learners to acquire the needed knowledge, skills and attitudes to make informed decision that engender self-emancipation and societal transformation. Some of the impediments to entrepreneurship and self-employment readiness of learners in the schools are insufficient fund, inadequate human and non-human instructional resources, and lack of innovative and experiential pedagogical strategies, among others. Among several strategies that can promote self-employment readiness in the learners are incessant visits to industries, establishment of mini enterprises, and collaboration with NGOs to carry out marketing activities in the society. Undiyaundeye and Otu (2015) lay emphasis on the need for business incubators in any entrepreneurship programme that must engender selfemployment readiness of the learners. Learners should be exposed to the realities in business establishments by making all the necessary modern instructional resources that can equip them with requisite marketing skills and competences adequately available in the schools.

It was found in a study carried out by Ukala (2018) that insufficient supply of the necessary instructional materials and facilities, among others, was adversely affecting the effective teaching and learning of trade subjects in senior secondary schools in Rivers State, Nigeria. Okoye and Udoudo (2015) also discovered that lack of adequate facilities and equipment has been a major impediment to the achievement of full acquisition of entrepreneurship/vocational skills among secondary school students in Nigeria. Adeyonu and Carim-Sanni (2015) came up with the findings that instructional materials, facilities and equipment were not adequately provided for the effective implementation of trade subjects in senior secondary schools. It was also found that most of the students were unable to acquire the requisite skills for job creation, poverty eradication and sustainability at graduation. Yusuf (2018) found in the research conducted on entrepreneurship skills acquired by students in trade subjects in Kano State, Nigeria, that students had been exposed to a various skills and knowledge but had limited evidence of self-employment readiness. However, Murniati, Tentama and Santosa (2020) found the positive influence of 
vocational education on junior high school students' entrepreneurial intention and ability to sell the grown crops in the market of the immediate community.

\section{RESEARCH METHOD}

The purpose of the study was to assess the availability and functionality of the recommended instructional resources in the actual implementation of Marketing Trade subject at senior secondary schools in Lagos State, Nigeria.

1. What is the availability of the recommended instructional resources for the effective implementation of Marketing Trade subject in senior secondary schools, Lagos State, Nigeria?

2. What is the extent to which students acquire marketing competences, through Marketing Trade subject, for self-employment readiness in senior secondary schools, Lagos State, Nigeria?

3. What is the students' rating of their self-employment readiness through Marketing Trade subject in senior secondary schools, Lagos, Nigeria?

There is no significant relationship between marketing competences acquired and self-employment readiness of students in senior secondary schools, Lagos State, Nigeria.

The descriptive survey research design was adopted for the study. The population of the study comprised 1367 students and all teachers of Marketing Trade subject in the selected public senior secondary schools in Education District IV of Lagos State, Nigeria. The sample of the study comprised 308 students and the available 9 teachers of Marketing Trade subject randomly and purposively selected respectively from the ten sampled senior secondary schools within Education District IV of Lagos State, Nigeria. The research instruments used were questionnaire and checklist. The internal consistency of the research instruments was determined using Cronbach Alpha correlation coefficient and it yielded an average index of 0.88 . Data analyses were done using descriptive statistics such as bar-chart, mean and standard deviation to answer the research questions while the hypothesis formulated was tested using the Pearson's Product Moment Correction statistical tool at 0.05 level of significance at relevant degrees of freedom using Statistical Package for Social Sciences (SPSS). The decision rule was based on any calculated mean scores, such as 3.5 and above is for "to a high extent"; $2.5-3.49$ is for "to a moderate extent"; 1.5-2.29 is for "to a low extent"; while below 1.5 is for "almost non-existent". Further, the value (p) was used in taking the decisions on the hypothesis. If the p-value is less than or equal to 0.05 , the null hypothesis is not retained, but if the p-value is greater than 0.05 , the null hypotheses is retained.

\section{RESULTS AND DISCUSSION}

Research Question One:

What is the availability of the recommended instructional resources for the effective implementation of Marketing Trade subject in senior secondary schools, Lagos State, Nigeria?

The analysis of data collected for research question one, through the use of a checklist, is categorized under three classifications such as Electrical/Electronic resources, Physical Facilities/Simple machines, and Print/Real Objects resources. Teachers of Marketing Trade subject in each schools assisted in getting information for the checklist used.

Availability of Electrical/Electronic Instructional Resources for Marketing Trade Subject in Secondary Schools. 


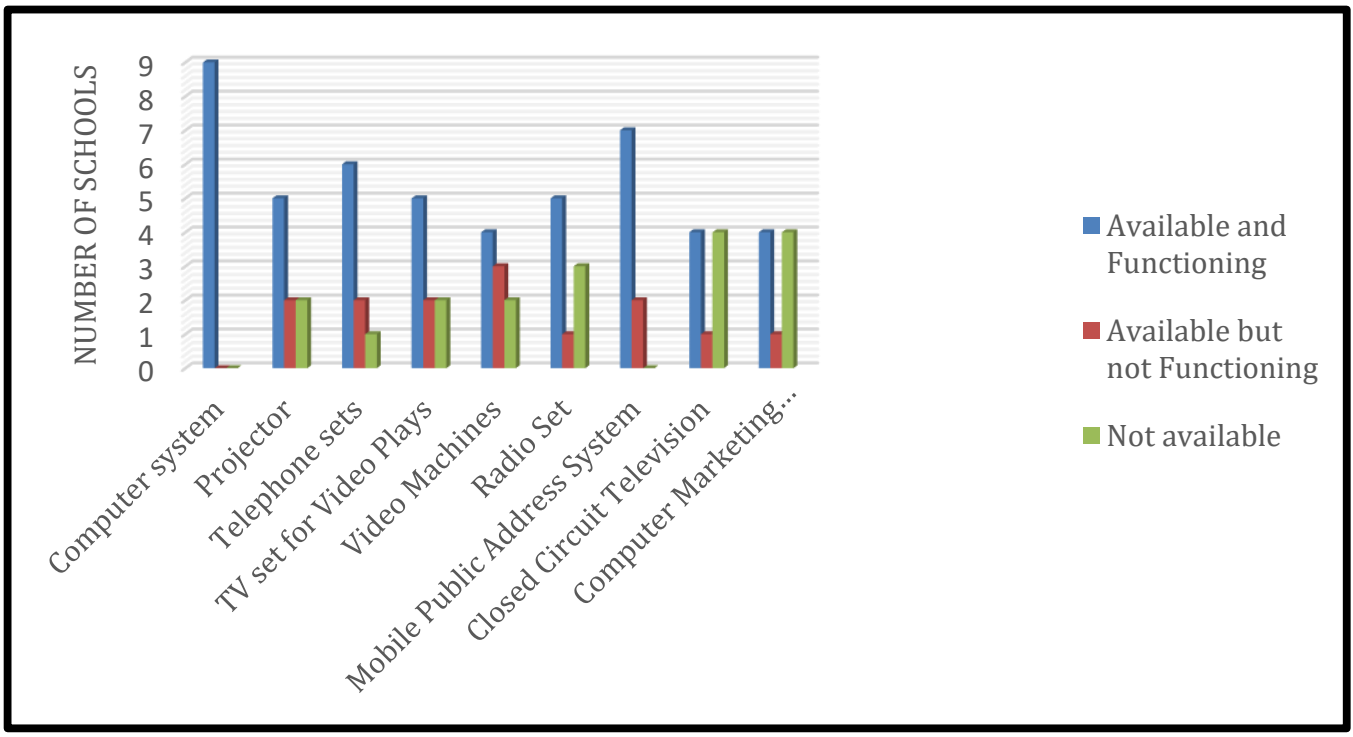

Figure 1. Electrical-Electronic Instructional Resources In Schools

The results displayed in figure 1 show that all the respondents (100\%) indicated that Computer Systems were available and functioning. 55.6\% of the respondents indicated that Projector, TV Set for Video Plays, and Radio set were available and functioning. $44.4 \%$ of the respondents indicated that Video Machines, Close Circuit Television, and Computer Marketing Software Package were available and functioning. $66.7 \%$ and $77.8 \%$ of the respondents indicated that Telephone Set and Mobile Public Address System respectively were available and functioning for the teaching and learning of Marketing Trade subject in the sampled senior secondary schools in Lagos State, Nigeria.

Availability of Physical Facilities/Simple Machines Instructional Resources for Marketing Trade Subject in Secondary Schools.

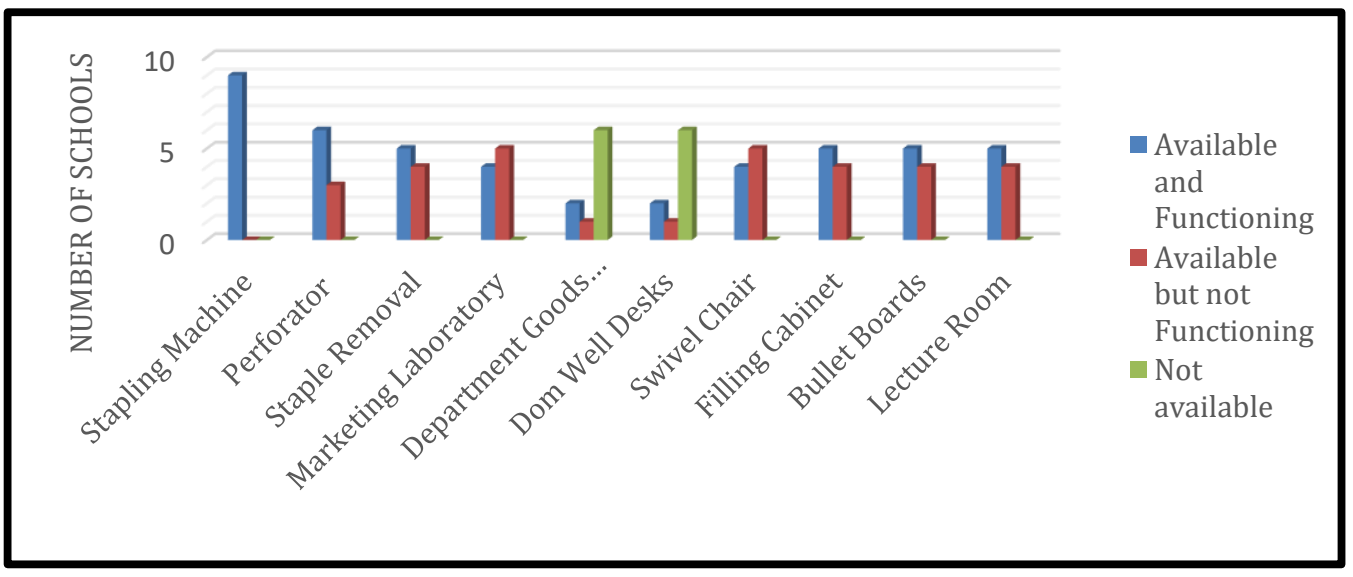

Figure 2. Physical facilities/simple machines instructional resources in schools

Figure 2 shows that $100 \%$ and $66.7 \%$ of the respondents indicated that stapling machine and Perforator were available and functioning. $55.6 \%$ of the respondents indicated that Staple Removal, Filling Cabinet, Bullet Boards, and Lecture Room were available and functioning. On the other hand, $66.7 \%$ of the respondents indicated nonavailability of Department Goods Shop and Dom Well Desks. Similarly, 55.6\% of the 
respondents indicated that Marketing Laboratory and Swivel Chair were available but not functioning for the teaching and learning of Marketing Trade subject in the sampled senior secondary schools in Lagos State, Nigeria.

Availability of Print/Real Objects Instructional Resources for Marketing Trade Subject in Secondary Schools.

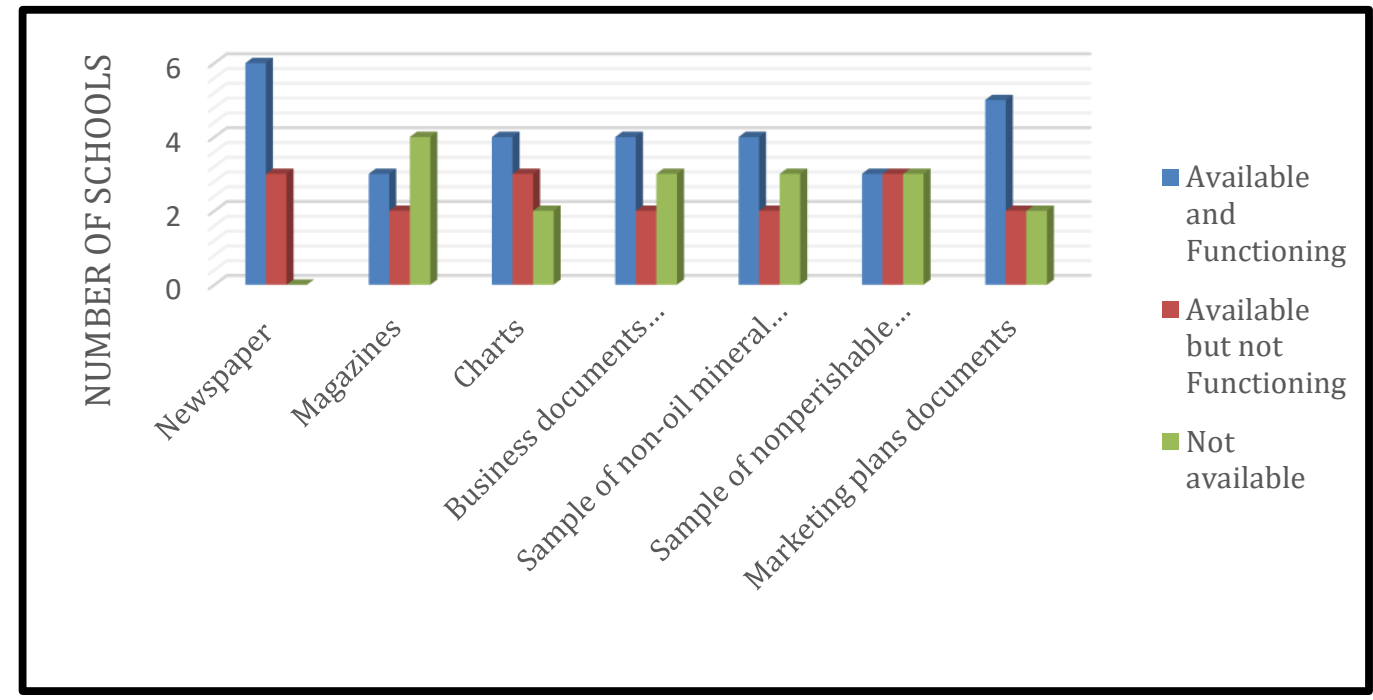

Figure 3. Print/Real object instructional resources in schools

The results presented in figure 3 show that $66.7 \%$ and $55.6 \%$ of the respondents indicated that newspaper and marketing plans documents were available and functioning. Surprisingly, $44.4 \%$ of the respondents indicated that charts, business documents specimens, and sample of non-oil mineral products were available and functioning. Pitiably, only $33.3 \%$ of the respondents indicated the availability and functionality of magazines and sample of non-perishable consumer goods for the teaching and learning of Marketing Trade subject in the sampled senior secondary schools in Lagos State, Nigeria.

Research Question Two: What is the extent to which students acquire marketing competences, through Marketing Trade subject, for self-employment readiness in senior secondary schools, Lagos State, Nigeria?

Table 1. The Extent of Marketing Competences Acquired by Students.

\begin{tabular}{llcll}
\hline S/N & Statement & Mean & SD & Remark \\
\hline 1. & Knowledge or marketing and its function in & & & To a moderate extent \\
& Nigeria & 3.21 & 1.04 & \\
2. & Knowledge of marketing concepts & 3.46 & 0.75 & To a moderate extent \\
3. & Knowledge of consumer behaviour & 3.41 & 0.79 & To a moderate extent \\
4. & Knowledge of marketing planning and research & 3.31 & 0.88 & To a moderate extent \\
5. & Knowledge of international marketing & 2.86 & 1.07 & To a moderate extent \\
6. & Ability to use ICT and internet for marketing & & & To a moderate extent \\
& activities & 2.84 & 1.03 & \\
7. & Ability to identify and successfully market a & & & To a moderate extent \\
& product or services to a target market & 3.09 & 0.92 & \\
8. & Ability to budget and forecast sales of products or & & & To a moderate extent \\
& service & 2.93 & 0.93 & \\
9. Ability to negotiate sales effectively & 3.06 & 0.95 & To a moderate extent \\
10. Ability to use sales promotion tools & 3.02 & 0.94 & To a moderate extent
\end{tabular}


11. Ability to set up a marketing outlet as an entrepreneur

12. Ability to market a product or services using electronic or social media marketing techniques Grand Mean

$\begin{array}{lll} & & \text { To a moderate extent } \\ 3.00 & 0.98 & \\ & & \text { To a moderate extent } \\ 2.98 & 1.01 & \\ 3.09 & & \text { To a moderate extent }\end{array}$

The results presented on table 1 show that majority of the students indicated that they have acquired marketing competences to a moderate extent in the following areas: knowledge or marketing and its function in Nigeria, knowledge of marketing concepts, knowledge of consumer behaviour, knowledge of marketing planning and research, as well as knowledge of international marketing. Similarly, majority of the students' respondents indicated that they had the ability to use ICT and internet for marketing activities, ability to identify and successfully market a product or services to a target market, ability to budget and forecast sales of products or service, ability to negotiate sales effectively, ability to use sales promotion tools, ability to set up a marketing outlet as an entrepreneur, and ability to market a product or services using electronic or social media marketing techniques. Moreover, the grand mean show that all the marketing skills and competences have been acquired by students to a moderate extent.

Research Question Three: What is the students' rating of their self-employment readiness through Marketing Trade subject in senior secondary schools, Lagos, Nigeria?

Table 2. Students' Rating of Self-Employment Readiness

\begin{tabular}{|c|c|c|c|c|}
\hline $\mathrm{S} / \mathrm{N}$ & Statement & Mean & SD & Remark \\
\hline 1. & $\begin{array}{l}\text { I will still need some training on marketing before I can really } \\
\text { practice marketing as an occupation. }\end{array}$ & 3.15 & .90 & Agreed \\
\hline 2. & $\begin{array}{l}\text { Marketing subject needs to be taught better than it is now for } \\
\text { me to be able to practice marketing as a business }\end{array}$ & 3.19 & .91 & Agreed \\
\hline & Grand Mean & 3.17 & & Agreed \\
\hline
\end{tabular}

The results presented in table 2 show that most of the students agreed that they would still need some training on marketing before they can really practice marketing as an occupation. In addition, majority of the students' respondents agreed that the teaching and learning of Marketing Trade subject needed to be improved upon for them to be able to practice marketing as a business. The grand mean of 3.17 show that the respondents have an unfavourable self-employment readiness rating.

Test of Hypothesis

"There is no significant relationship between marketing competences acquired and self-employment readiness of students in senior secondary schools, Lagos State, Nigeria".

Table 3. Relationship between students' marketing competences acquired and selfemployment empowerment

\begin{tabular}{llllllll}
\hline Variable & $\mathrm{N}$ & Mean & Sd & Df & r-calc & Sig & Decision \\
\hline Marketing Competences & 308 & 37.19 & 6.01 & & & \multirow{2}{*}{0.000} & Significant \\
Self-employment Readiness & 308 & 12.89 & 1.99 & & & & \\
\hline
\end{tabular}

The results presented in table 3 show the relationship between marketing competences $($ Mean $=37.19$ ) and self-employment readiness of the students (Mean = 12.89). The relationship between the two variables was significant $(r=0.36, p<0.05)$. Therefore, the null hypothesis was rejected. This implies that students' marketing competences influence their readiness for self-employment. 


\section{Discussion Of Findings}

The findings of the study are discussed below:

The results in figure 1 reveal the state of the available recommended electrical/electronic instructional resources for the teaching and learning of Marketing Trade subject in the sampled secondary schools in Lagos State. The findings show that computer systems, projector, TV set for video plays, radio set, telephone set, mobile public address system, as recommended in the curriculum, were available in more than fifty percent (50\%) of the sampled schools. However, the expected results is a hundred percent $(100 \%)$ availability and functionality of all the recommended resources. There were still some schools within the sampled population where the availability and functionality of the recommended instructional resources were inadequate. Specifically, majority of the schools (55.6\%) were not supplied with the recommended video machines, close circuit television and computer marketing software package for the teaching and learning of Marketing Trade subject. It can be summarized that the recommended electrical/electronic instructional resources were not adequately provided for the effective pedagogy of Marketing Trade subject in the sampled senior secondary schools in Lagos State, Nigeria. This finding corresponds with the results of Ukala (2018) whose research outcomes revealed that insufficient instructional resources had adverse effect on the teaching and learning of trade subjects in the schools. The situation here has serious implications on the achievement of the goals and objectives of Marketing Trade subject in the schools. Marketing skills and competences can only be adequately acquired when all the recommended and relevant instructional resources are sufficiently provided by the stakeholders. Solving youths' unemployment and its associated crises in the communities would be a mirage if a vocational/entrepreneurial subject such as Marketing Trade subject were allowed to suffer from dearth of required resources in the schools.

The findings in figure 2 show the availability of the recommended physical resources and simple machines for the teaching and learning of Marketing Trade subject in the selected secondary schools, Lagos State, Nigeria. It could be deduced from the results in figure 2 that only the simple tools such as stapling machine, perforator, staple removal, filing cabinet, as well as physical facilities such as classrooms, were available and functioning in more than average number of the sampled schools. As simple as those instructional resources appear to be, some schools (in the minority) were still being deprived of them. The findings in figure 2 also reveal that some modern instructional resources that can engender or enhance acquisition of the twenty-first century competences by the learners, were found to be non-available and not-functioning in about $55.6 \%$ of the sampled schools. Certain instructional resources such as Department Goods Shops, Dom Well Desks, Marketing Laboratory, and Swivel Chairs, which are needed for the acquisition and practical demonstration of emerging competences, were found to be inadequately supplied in the sampled schools. Marketing Trade subject is a practical-oriented subject that demands full engagement of students in practical demonstration of marketing activities both within and beyond the school environment. Therefore, non-availability and malfunctioning of the aforementioned modern instructional resources would deter students from gaining practical skills and exposures. In summary, the recommended physical facilities were inadequately supplied for the teaching and learning of Marketing Trade subject in the sampled secondary schools in Lagos State, Nigeria. This finding corroborates that of Okoye and Udoudo (2015) who discovered that facilities and equipment were inadequate in the schools and it hinders students' vocational/entrepreneurship skills acquisition.

Prominent among the recommended instructional resources for the teaching and learning of Marketing Trade subject are print materials and real objects. The findings in figure 3 show that newspapers and marketing plan documents were available and functioning in $66.7 \%$ and $55.6 \%$ of the sampled schools respectively. However, some other 
print and real objects resources such as charts, business documents specimens, magazines, sample of non-oil mineral products, and sample of non-perishable consumer goods, were not adequately available nor functioning in most of the schools. The results in figure 3 reveal that neither print materials nor real objects instructional resources were adequately available for the teaching and learning of Marketing Trade subject in the sampled schools in Lagos State, Nigeria. It is quite pathetic to note that as cheap-to-get as the recommended print materials and real objects instructional resources seem to be, they were not adequately available in most of the sampled schools for the teaching and learning of Marketing Trade subject. It is therefore doubtful whether the government and other stakeholders are actually interested and ready to effectively implement the trade subject in question. The project of introducing Marketing Trade subject into secondary schools in Nigeria will amount to white elephant if the stakeholders choose not to be fully responsible for its ideal implementation both materially and functionally.

The study also assesses the extent of marketing competences acquired by students as reflected in table 1 . The findings show that all the identified competences were moderately acquired by students of Marketing Trade subject. This result is similar to the research findings of Adeyonu and Carim-Sanni (2015) that skills acquired by students for poverty eradication and sustainability were inadequate due to insufficient supply of relevant instructional resources in the schools. The students acquired none of the competences to a high extent. Since the extent of acquisition of the requisite marketing competences has effect on the decision, ability and readiness of students for selfemployment, addressing the issues of inadequacy of instructional resources should be the priority of the stakeholders.

The findings in table 2 unveil the truth about students' readiness for self-employment through Marketing Trade subject. The findings show that students were not sure of their self-efficacy for practicing or establishing marketing businesses at graduation. Students' respondents emphasized the need for further training and more effective pedagogies for them to be fully ready for self-employment as marketers and entrepreneurs. Yusuf (2018) also had similar findings that skills acquired did not influence students' readiness for selfemployment. On the contrary, the findings of Murniati, Tentama and Santosa (2020) found the positive influence of vocational education on junior high school students' entrepreneurial intention and ability to sell the grown crops in the market of the immediate community. Therefore, the outcome of this study cannot be dissociated from the inadequacies in the availability and functionality of the recommended instructional resources in the sampled schools. If this situation continues without urgent intervention, the products of Marketing Trade subject would become additional liabilities to the Nigerian economy instead of being agents of social, economic and environmental transformation in this twenty-first century era.

It is discovered in table 3 that students' marketing competences influence their readiness for self-employment. The results of the hypothesis therefore reveal that there was a significant relationship between marketing competences acquired and self-employment readiness of students in the sampled senior secondary schools in Lagos State, Nigeria. The results of Yusuf (2018) also confirm this finding. This implies that adequate instructional resources must be available in schools because proper acquisition of marketing competences is strongly connected to the state of instructional resources in the schools. Subsequently, the self-efficacy of students, because of proper acquisition of marketing competences, would engender courage and confidence in them to be self-employed as marketing professionals and entrepreneurs. Hence, the synergy between the achievement of the aims and objectives of Marketing Trade subject and the realization of job creation, wealth generation, poverty and hunger eradication, as well as sustainable development in Nigeria. 


\section{CONCLUSION}

The study assessed the extent of conformity between the recommended and the actual instructional resources available and functioning for the teaching and learning of Marketing Trade subject in selected public senior secondary schools, Lagos State, Nigeria. The extent of marketing competences acquired by students and their readiness for self-employment in marketing-related businesses were also covered in this study. As strategic as Marketing Trade subject is to the achievement of full employment for youths, poverty eradication, job creation, and sustainable development of the Nigerian economy, its implementation was inadequate in the schools. The recommended instructional resources were not adequately available and functioning in schools. Students' level of acquisition of marketing competences was below the expectation. As a result, students lacked the self-efficacy, courage and confidence to become self-employed as marketers or establish any marketingrelated business as entrepreneurs.

\section{REFERENCES}

Adeyonu, A. G., \& Carim-Sanni, A. (2015). Assessment of the new trade/entrepreneurship education in secondary schools: Evidence from rural and Urban Areas of Oyo State, Nigeria. British Journal of Education, Society and Behavioural Science, 5(1), 50-61.

Cotta, T. F. (2018). Enterprises and entrepreneurship education: guidance for UK higher education providers. Retrieved from https://www.qua.qc.uk>docs $>$ quas

Fasasi, R. A. (2014). Agriculture science methods. National Open University of Nigeria (NOUN). Pp.32. Retrieved from https://www.nou.edu.ng>files

Lackeus, M. (2015). Entrepreneurship in education: what, why, when, how. Entrepreneurship 360 background paper. European Commission (OECD). Pp 1-45.

Mbanefo, M. C., \& Eboka, O. C. (2017). Acquisition of innovative and entrepreneurial skills in basic science education for job creation in Nigeria. Science Education International, 28(3), 207-213.

McGrant, I. (2002). Materials evaluation and design for language teaching. Edinburgh: Edinburgh University Press.

Murniati, T., Tentama, F., \& Santosa, B. (2020). Vocational skills education to grow the junior high school students' work intention. Journal of Vocational Education Studies, 3(1), 3948.

Nicholas, B., \& Shubha, J. (2013). Skills for employability in Africa and Asia: Innovative secondary education for skills enhancement (ISESE). Phase 1 Synthesis Reports. Pp.164. Retrieved from https://www.r4d.org>uploads

Nigerian Educational Research and Development Council (2007). Marketing: senior secondary school trade curriculum. Abuja: NERDC Press.

Okoye, K. R. E. \& Udoudo, E. S. (2015). Vocationalisation of secondary education in Nigeria: issues, challenges and prospects. Journal of Education and Practice, 6(30), 71-76.

Olokundun, M., Falola, H. Stephen, I. \& Inelo, F. (2014). An assessment of the taught entrepreneurship program in Nigerian secondary schools. Merit Research Journal of Education and Review, 2(11), 257-275.

Orji, N. S. (2013). The new senior secondary education curricula: Trade/Entrepreneurship. Nigerian Educational Research and Development Council (NERDC). Retrieved from https://www.academia.edu/994114/The_Trade_Entrepreneurship_Curriculum_for_ Nigeria_Senior_Secondary_Schools

Sayuti, M., \& Mujiarto (2018). Employability skills in vocational high school context: An analysis of the KTSP curriculum. Journal of Vocational Education Studies, 1(2), 33-44.

Ukala, C. C. (2018). Management of trade/entrepreneurship education in public senior secondary schools for smooth transition into the world of works in Rivers State, Nigeria. International Journal of Business and Management Review, 6(10), 33-46. 
Undiyaundeye, F., \& Otu, E. A. (2015). Entrepreneurship skills acquisition and the benefits amongst the undergraduate students in Nigeria. European Journal of Social Sciences Education and Research, 5(1), 357-362.

Valerio, A., Parton, B., \& Robb, A. (2014). Entrepreneurship education and training programs around the world: Dimensions of success. Washington, D.C.: The International Bank for Reconstruction and Development/World Bank. Pg 58. Retrieved from www.openknowledge.worldbank.org $>$ bitstream $>$ handle

Yusuf, A. W. (2018). Assessment of the implementation of trade/entrepreneurship curricula in senior secondary schools as a veritable tool towards youth empowerment in Kano State Nigeria. Journal of Teaching and Teacher Education, 6(2), 185-193. 
